\title{
Major and minor element levels in Greek apicultural products
}

\author{
Maragou N.C..$^{*}$, Pavlidis G. ${ }^{1}$, Karasali H. ${ }^{{ }^{*}}$ and Hatjina F. ${ }^{2}$ \\ ${ }^{1}$ Laboratory of Chemical Control of Pesticides, Department of Pesticides Control and Phytopharmacy, Benaki Phytopathological Institute, \\ 8 St. Delta Street, Kifissia, 14561, Athens, Greece. \\ 2Division of Apiculture, Institute of Animal Science, Hellenic Agricultural Organization 'DEMETER', Nea Moudania, Greece. \\ Received: 21/12/2016, Accepted: 07/03/2017, Available online: 18/10/2017 \\ *to whom all correspondence should be addressed: e-mail: e.karassali@bpi.gr; n.maragou@bpi.gr
}

\section{Abstract}

In the present study, four beehive matrices (honey, propolis, pollen and bees), sampled from thirteen apiaries from Northern and Western Greece, were analyzed for the presence of $\mathrm{Cr}, \mathrm{Cu}, \mathrm{Mn}, \mathrm{Fe}, \mathrm{Zn}, \mathrm{Mg}$, and $\mathrm{Ca}$. The proposed method involved microwave digestion with $\mathrm{H}_{2} \mathrm{O}_{2}$ and $\mathrm{HNO}_{3}$, dilution with water and direct determination by flame atomic absorption spectrometry. The results showed that the levels of elements in all apicultural products present the following order: $\mathrm{Ca}>\mathrm{Mg}>\mathrm{Zn} \approx \mathrm{Fe}>\mathrm{Mn}>\mathrm{Cu}$. $\mathrm{Cr}$ was detected at LOD level $\left(0.3 \mu \mathrm{g} \mathrm{g}^{-1}\right)$ only in some pollen samples from industrial areas. The most abundant elements determined were $\mathrm{Ca}$ (3.42 $\mathrm{mg} \mathrm{g}^{-1}$ ) and $\mathrm{Mg}(1.5$ $\mathrm{mg} \mathrm{g}^{-1}$ ) in pollen and propolis. It was also demonstrated that all detected elements are accumulated at higher concentrations in pollen, propolis and bees and to a much lesser extent in honey. Dependence of the content of $\mathrm{Mg}$ in honey and of the content of $\mathrm{Zn}$ and $\mathrm{Cu}$ in pollen, on the geographical origin of samples was identified.

Keywords: micro-elements, macro-elements, honey, pollen, propolis, bees.

\section{Introduction}

Honey is a natural sweet commodity produced by honeybees which contains mainly simple sugars, water, proteins, flavonoids, phenolic compounds, free amino acids, organics acids, vitamins and all of the minerals that are essential to human health (Gonzalez-Miret et al. 2005; Formicki et al. 2013). It is used both as food and as medicine due to its high nutritional, antimicrobial, antibacterial and anti-inflammatory properties (Meliou and Chinou 2004, 2011; Kalogeropoulos et al., 2009; Tsiapara et al., 2009; Mandal and Mandal, 2011).

Bee pollen and propolis are bee products that also possess anti-inflammatory and antioxidant properties due to high concentrations of flavonoids and other phenolic compounds (Cowan 1999; Çelemli et al., 2013; Formicki et al., 2013). Pollen is an apicultural product collected from the male plant reproductive cells and used by the bees as the main protein and vitamin food source for the larvae (Yang et al., 2013). Each pollen pellet has a characteristic color, size, morphology, flavor and composition specific to the floral species and cultivar (Di Paola-Naranjo et al.,
2004). Pollen contains all nutrients that are necessary for plant growth and development, and it is rich in sugars, proteins, amino acids, lipids, vitamins, minerals, nucleic acids, enzymes, and phenolics (Yang et al., 2013). Pollen is also important for the health and development of the different bee life stages (Avni et al., 2014).

Propolis is produced by honeybees after mixing plant resins with their own secretions. This apicultural product has been proposed as a germicide for food packaging or as a chemical preservative in some food products (Tosi et al., 2007), and even as a natural agent against bee's pathogenic bacteria (Özkirim et al., 2015).

The main natural source of micro and macro elements in apicultural products is the consumption of plants by bees, as well as the soil composition on which plants grow (Eremia, Dabija and Dodon 2010). Certain elements are transported through the root system to plants and their composition in nectar reflects the soil characteristics. Although the amount of micro- and macro-elements depends on apicultural products' botanical origin (Gonzalez-Miret et al., 2005; Lachman et al., 2007), the environmental pollution should also be considered as an additional source of some micro and toxic elements in apicultural products such as $\mathrm{Cd}, \mathrm{Ni}, \mathrm{Cr}, \mathrm{Cu}, \mathrm{Fe}, \mathrm{Pb}$ and $\mathrm{Zn}$. These elements may jeopardize the quality and the safety of apicultural products, and exhibit a potential hazard to human health (Crane 1984; Pohl et al., 2009).

Several aspects of the quality of honey and other apicultural products have been studied during the last years. Numerous studies deal with the determination of macro, micro and toxic elements' content in apicultural products (Tuzen et al., 2007; Pohl et al., 2011; Van der Steen et al., 2011; 2015; Meli et al. 2015), often in order to use them as bioindicators (Jones 1987; Saunier et al. 2013; Krakowskaa 2015), to certify their geographical origin (Bilandzic et al. 2011; Batista et al., 2012; Bonvehí and Bermejo, 2013; Pellerano 2012; Conti et al., 2014), or to assess the quality of honey (Devillers et al., 2002; Lachman et al., 2007; Pisani et al., 2008). Other studies focus on the use of apiary products for biomonitoring of other environmental contaminants (Balayiannis and Balayiannis, 2008; Bargańska et al., 2016). 
Although apiculture is very popular in Greece and apicultural products are produced and consumed at a large national scale, very limited information is available on the quality of Greek apicultural products regarding the content of macro and microelements, as well as the contamination of these products by toxic elements (Farmaki and Thomaidis, 2008; Ioannidou et al., 2005). The aim of this study was to address this lack of information by generating data for the elemental composition of Greek honey, propolis, pollen, and honeybees. In particular, a reliable Flame Atomic Absorption Spectroscopy method in combination with microwave-assisted digestion was developed and validated for the determination of $\mathrm{Cr}, \mathrm{Cu}$, $\mathrm{Mn}, \mathrm{Fe}, \mathrm{Zn}, \mathrm{Mg}$, and $\mathrm{Ca}$ in honey, propolis, pollen, and honeybees, collected from several areas of Northern and Western Greece. The validated analytical method was applied to thirty-two samples and the content of the elements was determined and compared to corresponding data from other countries. Finally, statistical analysis was performed in order to examine the effect of the geographical origin on the elemental composition of the apicultural products.

\section{Materials and methods}

\subsection{Sampling}

Four beehive matrices (honey, propolis, pollen and bees) from thirteen apiaries from Northern and Western part of Greece were collected and provided by the local beekeepers, between spring 2013 and August 2014, from rural areas, industrialized areas and some agricultural areas near mines. Samples were stored at $-15^{\circ} \mathrm{C}$ in their original plastic container until analysis. In total, 32 samples were analysed for macro-elements ( $\mathrm{Mg}, \mathrm{Ca}$ ) and micro-elements ( $\mathrm{Zn}, \mathrm{Cu}, \mathrm{Fe}, \mathrm{Cr}$, and $\mathrm{Mn}$ ). The location of the sampling points along with the industrialized activities of the area is illustrated in the map of Figure 1 . The samples were classified in three groups based on the geographical origin, as presented in Table 1 (Group 1: Kozani/Sindos, Group 2: Chalkidiki and Group 3: Arta).

\subsection{Standards and materials}

Analytical grade standard solutions of $1 \mathrm{~g} \mathrm{~L}^{-1}$ of the following elements: chromium ( $\mathrm{Cr})$, zinc $(\mathrm{Zn})$, copper $(\mathrm{Cu})$, manganese ( $\mathrm{Mn})$, iron (Fe), calcium (Ca) and magnesium (Mg), metal-free water and $\mathrm{HNO}_{3}(65 \%)$ were purchased from Fisher Scientific (UK). $\mathrm{H}_{2} \mathrm{O}_{2}$ was obtained from Carlo Erba (France). Stock solutions of each element were prepared in $0.1 \mathrm{~mol} \mathrm{~L}^{-1} \mathrm{HNO}_{3}$. The stock solutions were used for further dilutions.

\subsection{Sample preparation, analytical determination and data analysis}

Figure 2 describes the flow chart of the analytical procedure followed for all the elements. An aliquot of the samples $(0.1-1 \mathrm{~g})$ was treated with $5 \mathrm{~mL}$ metal-free $\mathrm{HNO}_{3}$ (65\%) and $2.5 \mathrm{~mL} \mathrm{H} \mathrm{O}_{2}$ (30\%). The samples were digested in a microwave oven (MARS, model MD 9132, CEM Corporation, USA) in Omni XP-1500 tubes. The temperature program was as follows: $0-15 \min$ ramp to $210^{\circ} \mathrm{C}$ and hold another $15 \mathrm{~min}$ at $210^{\circ} \mathrm{C}$. Every microwave digestion cycle consisted of 8 samples, two blanks $(5 \mathrm{~mL}$ $\mathrm{HNO}_{3}(65 \%)$ and $\left.2.5 \mathrm{~mL} \mathrm{H} \mathrm{O}_{2}(30 \%)\right)$ and two spiked samples. After digestion, tubes were let to cool down, the pressure was carefully released and the yellow/brown gases were let to escape under sonication, until complete decolorization. After the removal of the gases the samples were quantitatively transferred to $25 \mathrm{~mL}$ volumetric flasks and were diluted with water.

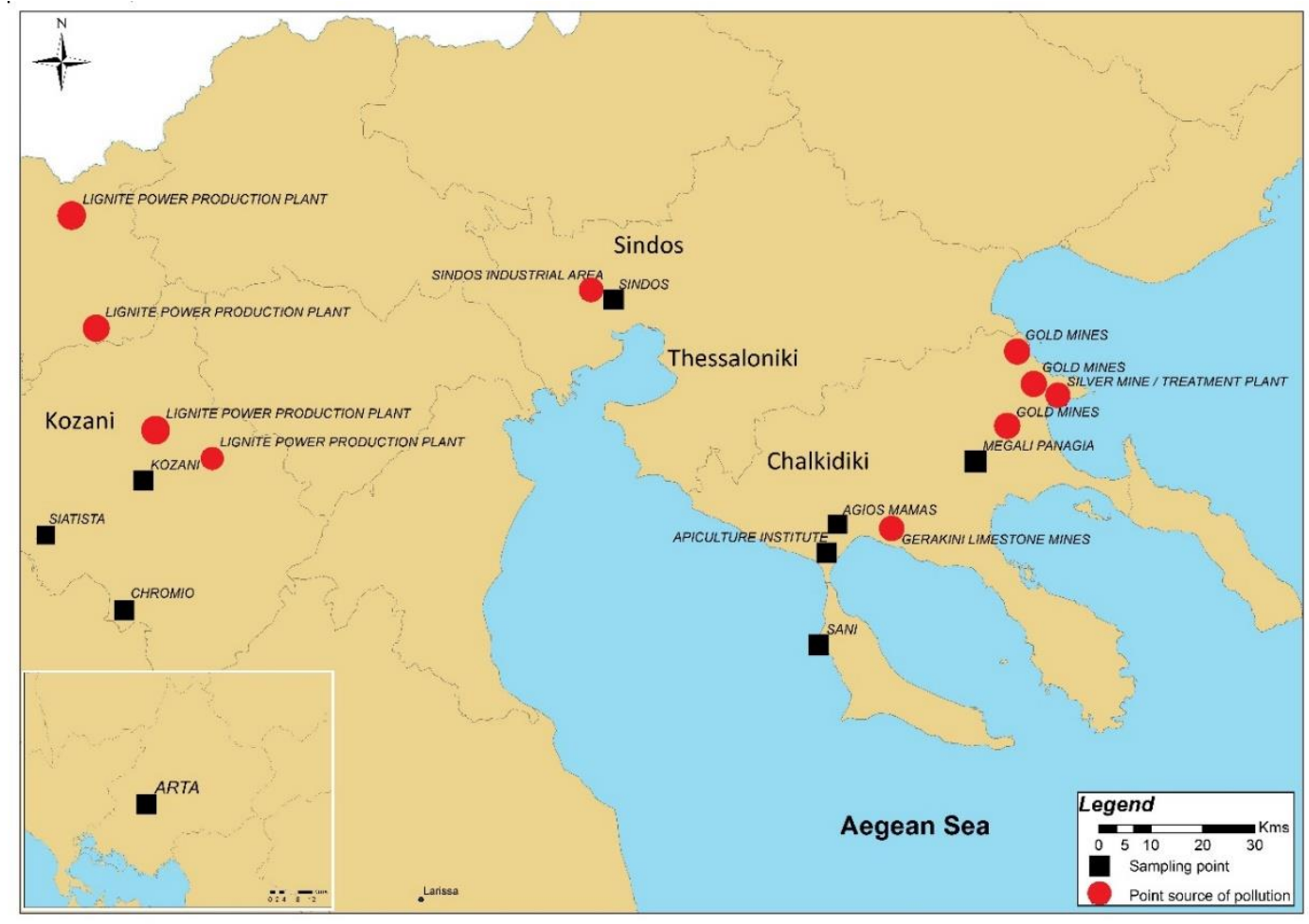

Figure 1. Sampling areas and industrialized activities 
Table 1. Origin of honey, propolis, pollen and bee samples

\begin{tabular}{|c|c|c|c|}
\hline $\mathbf{N}^{\circ}$ & Matrix & Sample name & Geographical region \\
\hline 1 & Honey & Kozani No 1 & Group 1 \\
\hline 2 & Honey & Kozani No 2 & Group 1 \\
\hline 3 & Honey & Sindos No 1 & Group 1 \\
\hline 4 & Honey & Sindos No 2 & Group 1 \\
\hline 5 & Honey & Apicult. Institute & Group 2 \\
\hline 6 & Honey & Sani & Group 2 \\
\hline 7 & Honey & Ag. Mamas & Group 2 \\
\hline 8 & Honey & M. Panagia & Group 2 \\
\hline 9 & Honey & Arta No 1 & Group 3 \\
\hline 10 & Propolis & Kozani No 1 & Group 1 \\
\hline 11 & Propolis & Sindos No 1 & Group 1 \\
\hline 12 & Propolis & Sindos No 2 & Group 1 \\
\hline 13 & Propolis & Apicult. Institute & Group 2 \\
\hline 14 & Propolis & Ag. Mamas & Group 2 \\
\hline 15 & Propolis & M. Panagia & Group 2 \\
\hline 16 & Pollen & Siatista & Group 1 \\
\hline 17 & Pollen & Chromio & Group 1 \\
\hline 18 & Pollen & Kozani No 1 & Group 1 \\
\hline 19 & Pollen & Kozani No 2 & Group 1 \\
\hline 20 & Pollen & Sindos No 1 & Group 1 \\
\hline 21 & Pollen & Sindos No 2 & Group 1 \\
\hline 22 & Pollen & Ag. Mamas & Group 2 \\
\hline 23 & Pollen & Apicult. Institute & Group 2 \\
\hline 24 & Pollen & Sani & Group 2 \\
\hline 25 & Pollen & M. Panagia & Group 2 \\
\hline 26 & Pollen & Arta No 1 & Group 3 \\
\hline 27 & Pollen & Arta No 2 & Group 3 \\
\hline 28 & Bees & Kozani No 1 & Group 1 \\
\hline 29 & Bees & Sindos No 1 & Group 1 \\
\hline 30 & Bees & Sindos No 2 & Group 1 \\
\hline 31 & Bees & Apicult. Institute & Group 2 \\
\hline 32 & Bees & M. Panagia & Group 2 \\
\hline
\end{tabular}

Flame atomic absorption spectrometer (Model AA-6500F, Shimadzu Corporation, Kyoto, Japan) with air-acetylene flame was used for the determination of $\mathrm{Cr}, \mathrm{Zn}, \mathrm{Cu}, \mathrm{Mn}, \mathrm{Fe}$, $\mathrm{Ca}$ and $\mathrm{Mg}$. For the determination of the macro-elements of $\mathrm{Ca}$ and $\mathrm{Mg}$, samples of pollen, propolis and bees were further diluted because of their high concentrations. The FAAS conditions applied were those proposed by the manufacturer.

The range of measured concentrations of each element for each matrix and the corresponding mean value were calculated. In cases where the element concentration was below the LOD, a value of LOD/ 2 was used for the statistical analysis and the calculation of the mean. The effect of the geographical region on the levels of the detected elements in honey, pollen and propolis was examined by performing t-test between Groups 1 and 2 which are described in Table 1. Group 3 was not used in the statistical analysis because of the limited number of samples. The statistical analysis was performed with the Excel program and a probability level of $p>0.05$ was considered statistically non-significant.

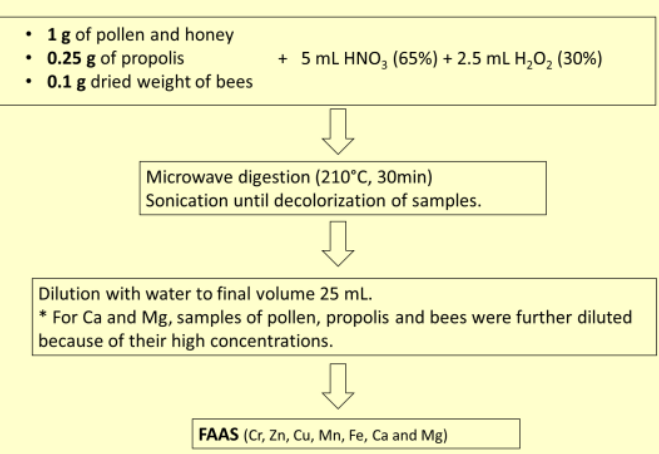

Figure 2. Flow chart of the analytical procedure

\subsection{Method validation}

Standard calibration curves were prepared daily by measuring standard solutions of the elements in 0.1 $\mathrm{mol} \mathrm{L}^{-1} \mathrm{HNO}_{3}$ at four calibration levels (Table 2). Linear regression analysis was performed using the absorbance against analyte concentration. 
For the assessment of the accuracy and the precision, the method was applied to honey, pollen, propolis and bee samples that were spiked with the measured elements at appropriate fortification levels (Table 3). Analysis of three replicates of the spiked samples was conducted for the repeatability test. The recovery was calculated by subtracting the concentration measured in the non-spiked sample from that measured in the spiked sample and then dividing with the spiked concentration.

For each of the four matrices the method limit of detection

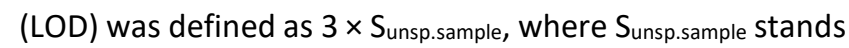
for the standard deviation of the response of 6 independent replicate analyses of the corresponding unspiked sample. In cases where no signal was obtained from the unspiked sample, the standard deviation of the response of a low level spiked sample was used for the determination of the LOD.

\section{Results and discussion}

\subsection{Method performance}

Table 2 presents the range of the calibration concentrations of the standard solutions, the linear regression lines and the squared correlation coefficients $\left(r^{2}\right)$ which all exceeded 0.99. The accuracy of the method expressed as \% recovery and the precision of the method expressed as \% RSD, are presented in Table 3. The reported fortification levels refer to the amount of the element $(\mu \mathrm{g})$ per amount of sample (g). The recoveries of the elements ranged between $70 \%$ and $115 \%$, except for $\mathrm{Cr}$ which was $56 \%$ and $65 \%$ in propolis and bees, respectively. The corresponding \% RSDs ranged between 1.4 and 20 .

Table 2. Calibration lines of standard solutions

\begin{tabular}{cccc}
\hline & Calibration range $\left(\mu \mathrm{g} \mathrm{mL}^{-1}\right)$ & Linear regression lines & $\mathbf{r}^{\mathbf{2}}$ \\
\hline $\mathrm{Cr}$ & $0.1-0.4$ & $\mathrm{y}=0.0227 \mathrm{x}+0.0023$ & 0.9999 \\
\hline $\mathrm{Cu}$ & $0.05-0.4$ & $\mathrm{y}=0.0437 \mathrm{x}+0.0031$ & 0.9939 \\
\hline $\mathrm{Mn}$ & $0.05-0.4$ & $\mathrm{y}=0.0403 \mathrm{x}+0.0031$ & 0.9978 \\
\hline $\mathrm{Zn}$ & $1-4$ & $\mathrm{y}=0.1274 \mathrm{x}+0.0545$ & 0.9998 \\
\hline $\mathrm{Fe}$ & $0.1-0.8$ & $\mathrm{y}=0.0177 \mathrm{x}+0.0041$ & 1.0000 \\
\hline $\mathrm{Ca}$ & $0.5-4$ & $\mathrm{y}=0.0251 \mathrm{x}+0.0066$ & 0.9994 \\
\hline $\mathrm{Mg}$ & $0.2-1.6$ & $\mathrm{y}=0.2296 \mathrm{x}-0.0012$ & 0.9949 \\
\hline
\end{tabular}

Table 3. Accuracy and precision data for all elements in all matrices $(n=3)$

\begin{tabular}{|c|c|c|c|c|c|c|c|c|c|c|c|c|}
\hline & \multicolumn{3}{|c|}{ Honey } & \multicolumn{3}{|c|}{ Propolis } & \multicolumn{3}{|c|}{ Pollen } & \multicolumn{3}{|c|}{ Bees } \\
\hline & $\begin{array}{l}\text { Fortification } \\
\text { level }\left(\mu g^{-1}\right)\end{array}$ & $\begin{array}{l}\text { Rec. } \\
\text { (\%) }\end{array}$ & \%RSD & $\begin{array}{l}\text { Fortification } \\
\text { level }\left(\mu \mathrm{g} \mathrm{g}^{-1}\right)\end{array}$ & $\begin{array}{l}\text { Rec. } \\
\text { (\%) }\end{array}$ & \%RSD & $\begin{array}{l}\text { Fortification } \\
\text { level }\left(\mu \mathrm{g} \mathrm{g}^{-1}\right)\end{array}$ & $\begin{array}{l}\text { Rec. } \\
(\%)\end{array}$ & \%RSD & $\begin{array}{l}\text { Fortification } \\
\text { level }\left(\mu \mathrm{g}^{-1}\right)\end{array}$ & $\begin{array}{l}\text { Rec. } \\
\text { (\%) }\end{array}$ & \%RSD \\
\hline $\mathrm{Cr}$ & 2.5 & 80 & 6.4 & 10 & 56 & 9.2 & 1 & 74 & 8.4 & 100 & 65 & $n=2$ \\
\hline $\mathrm{Cu}$ & 2.5 & 103 & 3.3 & 2.5 & 85 & 1.4 & 5 & 83 & 4.0 & 125 & 109 & 3.4 \\
\hline $\mathrm{Mn}$ & 2.5 & 115 & 3.5 & 5 & 108 & 9.1 & 25 & 80 & 4.9 & 125 & 107 & 20 \\
\hline $\mathrm{Zn}$ & 25 & 98 & 5.9 & 100 & 79 & 3.1 & 25 & 70 & 8.1 & 125 & 81 & 12 \\
\hline $\mathrm{Fe}$ & 5 & 91 & 12 & 50 & 103 & $(n=1)$ & 25 & 100 & 6.3 & 125 & 96 & 14 \\
\hline $\mathrm{Ca}$ & 50 & 93 & 14 & n.d & n.d & n.d & 500 & 82 & 10 & 1000 & 90 & 15 \\
\hline $\mathrm{Mg}$ & 20 & 93 & 7.6 & 200 & 96 & 3.3 & 250 & 100 & 14 & 500 & 86 & 2.5 \\
\hline
\end{tabular}

n.d: not determined

\subsection{Element concentrations in samples}

The concentration ranges of the elements in the analysed samples are summarized in Table 4 and the mean concentration of each element for each matrix is illustrated in Figure 3. The method limits of detection varied depending on the metal and the matrix analysed (Table 4).

$\mathrm{Cr}$ was detected only in pollen samples, in particular in the four samples of Kozani and in one sample of Sindos at the LOD level $\left(0.3 \mu \mathrm{g} \mathrm{g}^{-1}\right)$. Similar results for the content of $\mathrm{Cr}$ in pollen samples have been obtained from Poland (0.2 - 0.3 $\mu \mathrm{g} \mathrm{g}^{-1}$ ) (Grembecka and Szefer, 2013), and a wider range of concentrations has been determined in pollen samples from Canada, 0.54 - $22 \mu \mathrm{g} \mathrm{g}^{-1}$ (Cloutier-Hurteau et al., 2014). Concentration of $\mathrm{Cr}$ in honey has been found up to $0.5 \mu \mathrm{g} \mathrm{g}^{-1}$, higher content of $\mathrm{Cr}$ has been determined in propolis, 5.6 - $7.8 \mu \mathrm{g} \mathrm{g}^{-1}$ (Grembecka and Szefer, 2013) and concentration in worker honeybees from the Netherlands ranged between $0.15-0.28 \mu \mathrm{g} \mathrm{g}^{-1}$ dry matter (Van der Steen et al., 2011).
In the present study the most abundant element was $\mathrm{Ca}$ and the highest concentrations were found in samples of propolis with an average value of $2476 \mu \mathrm{g} \mathrm{g}^{-1}$. The mean content of $\mathrm{Ca}$ in pollen was $1345 \mu \mathrm{g} \mathrm{g}^{-1}$, in bees $1411 \mu \mathrm{g} \mathrm{g}^{-1}$ dry weight and in honey $43 \mu \mathrm{g} \mathrm{g}^{-1}$. The high content of $\mathrm{Ca}$ in pollen and in propolis is also verified with results obtained from corresponding matrices which range between 707 and $2020 \mathrm{\mu g} \mathrm{g}^{-1}$ (Stanciu et al., 2011; Grembecka and Szefer, 2013). Mg comes second in the order of concentration level for all examined matrices with mean values ranging between $33 \mathrm{\mu g} \mathrm{g}^{-1}$ for honey and 928

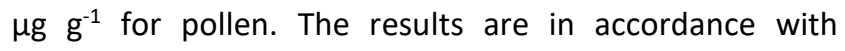
corresponding published results in honey from Poland ( $\mathrm{Ca}$ : 20 - $70 \mu \mathrm{g} \mathrm{g}^{-1}$; Mg: $6.5-60 \mu \mathrm{g} \mathrm{g}^{-1}$ ) (Grembecka and Szefer, 2013) and honey from the Czech Republic (Ca: $64.9 \mu \mathrm{g} \mathrm{g}^{-1}$; Mg: $50.1 \mu^{-1}$ g (Lachman et al., 2007), while higher values for $\mathrm{Ca}$ were determined in Croatian honey samples with mean value at $345.3 \mu \mathrm{g} \mathrm{g}^{-1}$ but similar for $\mathrm{Mg}, 23.9 \mu \mathrm{g} \mathrm{g}^{-1}$ (Bilandžić et al., 2014).

The mean concentration of $\mathrm{Zn}$ in honey, determined in the present study, was $6 \mu \mathrm{g} \mathrm{g}{ }^{-1}$, while the highest levels of this 
element was determined in propolis, $143 \mu \mathrm{g} \mathrm{g}^{-1}$; in dried bee samples, $104 \mu \mathrm{g} \mathrm{g}^{-1}$ and in pollen $71 \mu^{\mathrm{g} \mathrm{g}^{-1}}$ (Figure 3). Corresponding published data on the concentration of $\mathrm{Zn}$ in Czech (Lachman et al., 2007), Polish (Grembecka and Szefer, 2013) and Croatian honey (Bilandžić et al., 2014) report values between $0.2-8 \mu \mathrm{g} \mathrm{g}^{-1}$. Data on pollen and propolis from Poland report values between 27 and $44.8 \mu \mathrm{g}$ $\mathrm{g}^{-1}$ (Grembecka and Szefer, 2013), data on pollen from Canada report values between 59.5 and $205 \mu \mathrm{g} \mathrm{g}$ (Cloutier-Hurteau et al., 2014). Additionally, $\mathrm{Zn}$ values in worker honeybees was found to be in the range between 59.18 and $100.46 \mu \mathrm{g} \mathrm{g}^{-1}$ dry weight (Van der Steen, Kraker and Grotenhuis, 2011), which is in agreement with the results of the present study.

Fe was detected in three of the nine honey samples and the statistical mean concentration was $1 \mu \mathrm{g} \mathrm{g}^{-1}$. The highest levels of this element was determined in pollen, $169 \mathrm{\mu g} \mathrm{g}^{-1}$, in propolis, $88 \mathrm{\mu g} \mathrm{g}^{-1}$ and in dried bee samples, $83 \mu \mathrm{g} \mathrm{g}^{-1}$ (Figure 3). Corresponding published data on the concentration of $\mathrm{Fe}$ in Croatian and Polish honey report values between 0.6 and $6.7 \mathrm{\mu g} \mathrm{g}^{-1}$ (Grembecka and Szefer 2013; Bilandžić et al., 2014). Data on pollen and propolis from Poland report values between 32 and $48.9 \mu \mathrm{g} \mathrm{g}^{-1}$ (Grembecka and Szefer, 2013).

Mn was detected in only one honey sample, M. Panagia from Chalkidiki at a concentration of $0.7 \mu \mathrm{g} \mathrm{g}^{-1}$ (Table 4), while it was detected in all samples of pollen (mean: $29 \mu \mathrm{g}$ $\mathrm{g}^{-1}$ ) and in most of the propolis samples (mean: $10 \mu \mathrm{g} \mathrm{g}^{-1}$ ) and dried bees (mean: $17 \mu^{-1} g^{-1}$ ) (Figure 3). Corresponding published data on the concentration of $\mathrm{Mn}$ in Czech and Polish honey report values between $0.1-4.7 \mu \mathrm{g} \mathrm{g}^{-1}$ (Lachman et al., 2007; Grembecka and Szefer, 2013). Data on pollen and propolis from Poland report values between 14 and $24.7 \mu^{-1} g^{-1}$ (Grembecka and Szefer, 2013) and data on pollen from Canada report values between 19.7 and 117 $\mu \mathrm{g} \mathrm{g}^{-1}$ (Cloutier-Hurteau et al., 2014). It should be noted that similar values were determined for $\mathrm{Mn}$ in honeybees from the Netherlands (Van der Steen, et al., 2011)

$\mathrm{Cu}$ was detected in all honeybee samples at mean concentration $16 \mu \mathrm{g} \mathrm{g}^{-1}$ dried weight and in all pollen samples at mean concentration $9 \mu \mathrm{g} \mathrm{g}^{-1}$. Regarding propolis only half of the samples were found to contain $\mathrm{Cu}$ at concentrations up to $6.1 \mu \mathrm{g} \mathrm{g}^{-1}$, while it was not determined in none of the honey samples. Regarding the content of $\mathrm{Cu}$ in honey bees, similar results were presented by other studies (Roman 2010; Van der Steen et al., 2011). According to Roman, (2010), Cu was an element present in bodies of worker honeybees with a mean content of 22.6 $\mu \mathrm{g} \mathrm{g}^{-1} \mathrm{~d} . \mathrm{m}$, whereas $\mathrm{Cu}$ accumulation in honey was at a concentration many fold lower: $\mathrm{Cu}-0.82 \mu \mathrm{g} \mathrm{g} \mathrm{g}^{-1} \mathrm{~d} . \mathrm{m}$. Additionally, other studies determined $\mathrm{Cu}$ in Czech honey (Lachman et al., 2007) and Polish honey (Grembecka and Szefer, 2013) between 0.1 and $2.2 \mu \mathrm{g} \mathrm{g}^{-1}$, while higher values are reported for Croatian honey, mean of 14.4 $\mu \mathrm{g} \mathrm{g}^{-1}$ (Bilandžić et al., 2014). Data on pollen and propolis from Poland report values between 3.6 and $11.2 \mu \mathrm{g} \mathrm{g}^{-1}$ (Grembecka and Szefer, 2013) and data on pollen from Canada report values between 0.54 and $27.7 \mu \mathrm{g} \mathrm{g}^{-1}$ (Cloutier-Hurteau et al., 2014).

The statistical analysis showed that there is a significant difference in the content of $\mathrm{Mg}$ in honey $\left(\mathrm{N}_{1}=4, \mathrm{~N}_{2}=4\right.$, $\mathrm{p}=0.040)$, and in the content of $\mathrm{Zn}\left(\mathrm{N}_{1}=6, \mathrm{~N}_{2}=4, \mathrm{p}=0.027\right)$ and $\mathrm{Cu}\left(\mathrm{N}_{1}=6, \mathrm{~N}_{2}=4, \mathrm{p}=0.037\right)$ in pollen, from the two tested geographical areas. Correlation between the micro-, macro- and trace elements' content of the apicultural products and their geographical origin has been reported in other studies as well (Gonzalez-Miret et al., 2005; Lachman et al., 2007; Van der Steen et al., 2011).

Chromium was detected at the LOD level $\left(0.3 \mu \mathrm{g} \mathrm{g}^{-1}\right)$ in five out of six pollen samples of Group 1 (Kozani/Sindos), whereas it was not detected in samples of the other geographical origin. These findings could possibly be attributed to the specific industrialized zone areas; however, no safe conclusion can be drawn as the nonquantifiable data did not permit a statistical analysis.

It is noted that all the samples of the present study were also measured for $\mathrm{Cd}$ and $\mathrm{Pb}$. However, no detection was observed as the LODs for these toxic elements were $\geq 0.5$ $\mu \mathrm{g} \mathrm{g} \mathrm{g}^{-1}$.

Table 4. Major and minor element concentration ranges ( $\min$ - max) expressed as $\mu \mathrm{g} \mathrm{g}^{-1}$ in the four different matrices (n: number of samples)

\begin{tabular}{|c|c|c|c|c|}
\hline & Honey $(n=9)$ & Propolis $(n=6)$ & Pollen $(n=12)$ & Bees ${ }^{*}$ Dry weight $(\mathrm{n}=5)$ \\
\hline $\mathrm{Ca}$ & $\begin{array}{c}<\text { LOD up to } 73.6 \\
(\text { LOD }=40)\end{array}$ & $1462-3418$ & $544-2472$ & $1106-1877$ \\
\hline Mg & $13.6-74.5$ & $284-401$ & $411-1496$ & $655-1147$ \\
\hline Zn & $\begin{array}{c}<\text { LOD up to } 33.9 \\
\quad(\text { LOD }=2.8)\end{array}$ & $30.7-383.8$ & $41.1-93.9$ & $86.1-149.5$ \\
\hline $\mathrm{Fe}$ & $\begin{array}{c}<\text { LOD up to } 2.0 \\
\quad(\text { LOD }=1.8)\end{array}$ & $78.2-433$ & $49.3-199.1$ & $49.4-113.9$ \\
\hline$M n$ & $\begin{array}{c}<\text { LOD up to } 0.7 \\
\quad(\operatorname{LOD}=0.3)\end{array}$ & $\begin{array}{c}<\text { LOD up to } 24.6 \\
(\text { LOD }=1.3)\end{array}$ & $14.4-63.6$ & $\begin{array}{c}<\text { LOD up to } 69.7 \\
(\text { LOD }=3.2)\end{array}$ \\
\hline $\mathrm{Cu}$ & $<\operatorname{LOD}(\operatorname{LOD}=0.6)$ & $\begin{array}{c}<\text { LOD up to } 6.1 \\
\quad(\text { LOD }=2.5)\end{array}$ & $5.7-15.1$ & $12.7-23.4$ \\
\hline $\mathrm{Cr}$ & $<\operatorname{LOD}(\operatorname{LOD}=0.7)$ & $<\operatorname{LOD}(\operatorname{LOD}=3)$ & $\leq \operatorname{LOD}(\operatorname{LOD}=0.3)$ & $<\operatorname{LOD}(\operatorname{LOD}=7.5)$ \\
\hline
\end{tabular}

LOD: method limit of detection 


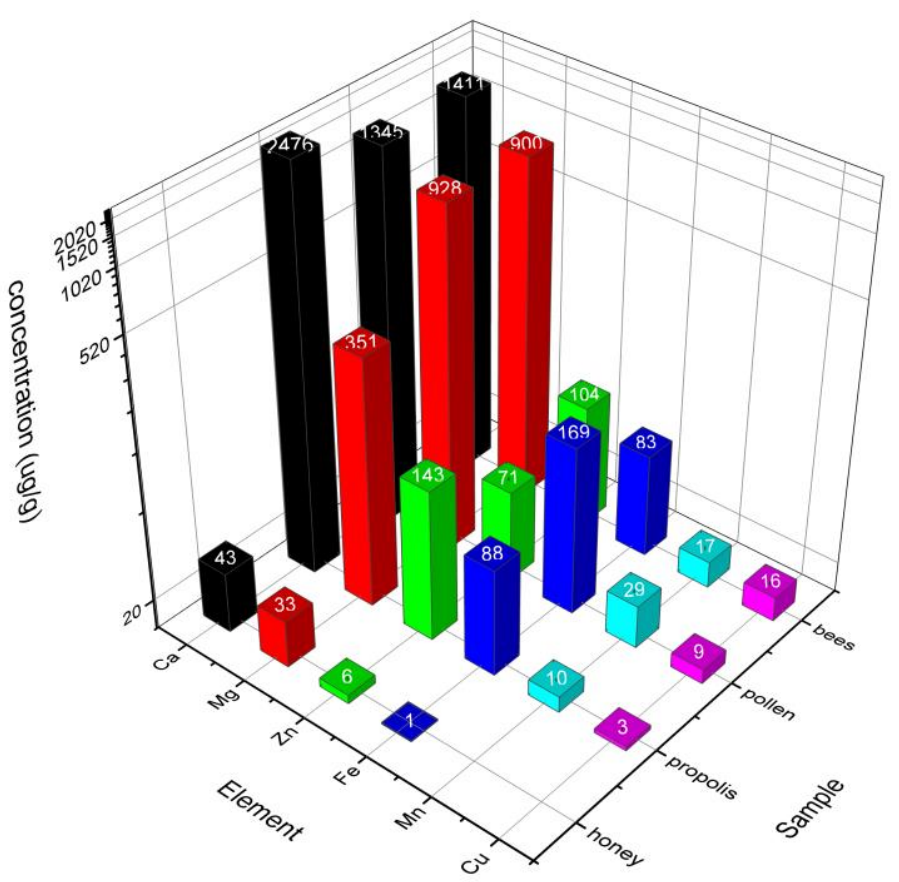

Figure 3. Graph of the mean concentrations $\left(\mu \mathrm{g} \mathrm{g}^{-1}\right)$ of measured elements in honey, propolis, pollen and bee samples

\section{Conclusions}

In the present study it is demonstrated that the levels of elements in honey, propolis, pollen and bees present the following order: $\mathrm{Ca}>\mathrm{Mg}>\mathrm{Zn} \approx \mathrm{Fe}>\mathrm{Mn}>\mathrm{Cu}$. It is noted that $\mathrm{Cu}$ was not detected in honey and $\mathrm{Mn}$ was detected in only one honey sample. $\mathrm{Cr}$ was detected only in pollen samples, in particular in the five out of six samples of Kozani and Sindos at LOD level $\left(0.3 \mu \mathrm{g} \mathrm{g}^{-1}\right)$, possibly because of the industrialized zone area. It is also shown that all the detected elements are accumulated at higher concentrations in pollen, propolis and bees and to a much lesser extent in honey. Finally, statistical analysis showed that there is dependence of the content of $\mathrm{Mg}$ in honey and of the content of $\mathrm{Zn}$ and $\mathrm{Cu}$ in pollen, on the selected sampling areas of Northern and Western Greece. These data may act as the basis for further research.

\section{Acknowledgements}

This work was partly supported by an EC \& Greek Government project, awarded to Division of Apiculture- Hell. Agr. Org. 'DEMETER' under 797/2007 Directive of EC. We would also like to thank Dr. A. Papachristoforou for his assistance, the beekeepers who provided all the samples and the two Greek companies which also partly supported this project: Anel Standard Pantelakis (Beekeeping equipment) and APIVITA SA (Bee Products \& Herbs).

\section{References}

Avni D., Hendriksma H.P., Dag A., Uni Z. and Shafir S. (2014), Nutritional aspects of honey bee-collected pollen and constraints on colony development in the eastern Mediterranean, Journal of Insect Physiology, 69, 65-73.

Balayiannis G. and Balayiannis P. (2008), Bee honey as an environmental bioindicator of pesticides' occurrence in six agricultural areas of Greece, Archives of Environmental Contamination and Toxicology, 55(3), 462-470.
Bargańska Z., Ślebioda M. and Namieśnik J. (2016), Honey bees and their products: Bioindicators of environmental contamination, Critical Reviews in Environmental Science and Technology, 46(3), 235-248.

Batista B.L., Silva L.R.S., Rocha B.A., Rodrigues J.L., Berretta-Silva A.A., Bonates T.O., Gomes V.S.D., Barbosa R.M. and Barbosa F. (2012), Multi-element determination in Brazilian honey samples by inductively coupled plasma mass spectrometry and estimation of geographic origin with data mining techniques, Food Research International, 49(1), 209-215.

Bilandžic N., Đokic M., Sedak M., Kolanović B. S., Varenina I., Končurat A. and Rudan N. (2011), Determination of trace elements in Croatian floral honey originating from different regions, Food Chemistry, 128(4), 1160-1164.

Bilandžić N., Gačić M., Đokić M., Sedak M., Šipušić Đ. I., Končurat A. and Gajger I. T. (2014), Major and trace elements levels in multifloral and unifloral honeys in Croatia, Journal of Food Composition and Analysis, 33(2), 132-138.

Bonvehí J.S. and Bermejo F.J.O. (2013), Element content of propolis collected from different areas of South Spain, Environmental Monitoring and Assessment, 185(7), 60356047.

Çelemli O.G., Hatjina F., Charistos L., Schiesser A. and Özkirim A. (2013), More Insight into the Chemical Composition of Greek Propolis; Differences and Similarities with Turkish Propolis, Zeitschrift für Naturforschung, 68c, $429-438$.

Cloutier-Hurteau B., Gauthier S., Turmel M., Comtois P. and Courchesne F. (2014), Trace elements in the pollen of Ambrosia artemisiifolia: What is the effect of soil concentrations? Chemosphere, 95, 541-549.

Conti M.E., Finoia M.G., Fontana L., Mele G., Botrè F. and lavicoli I. (2014), Characterization of Argentine honeys on the basis of their mineral content and some typical quality parameters, Chemistry Central Journal, 8, 44.

Cowan M.M. (1999), Plant products as antimicrobial agents, Clinical Microbiology Reviews, 12(4), 564 - 582. 
Crane E. (1984), Bees, honey and pollen as indicators of metals in the environment, Bee World, 55(1), 47-49.

Devillers J., Dore J.C., Marenco M., Poirier-Duchene F., Galand N. and Viel C. (2002), Chemometrical analysis of 18 metallic and nonmetallic elements found in honeys sold in France, Journal of Agricultural and Food Chemistry, 50(21), 5998-6007.

Di Paola-Naranjo R.D., Sánchez-Sánchez J., González-Paramás A.M. and Rivas-Gonzalo J.C. (2004), Liquid chromatographic-mass spectrometric analysis of anthocyanin composition of dark blue bee pollen from Echium plantagineum, Journal of Chromatography A, 1054(1-2), 205-210.

Eremia N., Dabija T. and Dodon I. (2010), Micro- and Macroelements Content in Soil, Plants Nectaro-Pollenifer Leaves, Pollen and Bees Body, Animal Science and Biotechnologies, 43(2), 180-182.

Farmaki E.G. and Thomaidis N.S. (2008), Current status of the metal pollution of the environment of Greece - A Review, Global NEST Journal, 10(3), 366-375.

Formicki G., Gren A., Stawarz R., Zyśk B. and Gał A. (2013), Metal Content in Honey, Propolis, Wax, and Bee Pollen and Implications for Metal Pollution Monitoring, Polish Journal of Environmental Studies, 22(1), 99-106.

Grembecka M. and Szefer P. (2013), Evaluation of honeys and bee products quality based on their mineral composition using multivariate techniques, Environmental Monitoring and Assessment, 185(5), 4033-4047.

Gonzalez-Miret M.L., Terrab A., Hernanz D., FernandezRecamales M.A. and Heredia F.J. (2005), Multivariate Correlation between Color and Mineral Composition of Honeys and by Their Botanical Origin, Journal of Agricultural and Food Chemistry, 53(7), 2574-2580.

Jones K.C. (1987), Honey as an indicator of heavy metal contamination, Water, Air, and Soil Pollution, 33(1), 179-189.

Ioannidou M.D., Zachariadis G.A., Anthemidis A.N. and Stratis J.A. (2005), Direct determination of toxic trace metals in honey and sugars using inductively coupled plasma atomic emission spectrometry, Talanta, 65(1), 92-97.

Kalogeropoulos N., Konteles S.J., Troullidou E., Mourtzinos I. and Karathanos V.T. (2009), Chemical composition, antioxidant activity and antimicrobial properties of propolis extracts from Greece and Cyprus, Food Chemistry, 116(2), $452-461$.

Krakowskaa A., Muszyńskab B., Reczyńskia W., Opokac W. and Turskid W. (2015), Trace metal analyses in honey samples from selected countries. A potential use in bio-monitoring, International Journal of Environmental Analytical Chemistry, 95(9), 855-866.

Lachman J., Kolihova D., Miholová D., Košata J., Titěra D. and Kult K. (2007), Analysis of minority honey components: Possible use for the evaluation of honey quality, Food Chemistry, 101(3), 973-979.

Mandal M. D. and Mandal S. (2011), Honey: its medicinal property and antibacterial activity, Asian Pacific Journal of Tropical Biomedicine, 1(2), 154-160.

Meli M.A., Desideri D., Roselli C., Benedetti C. and Feduzi L. (2015), Essential and toxic elements in honeys from a region of central Italy, Journal of Toxicology and Environmental Health Part A, 78(10), 617-627.

Melliou E. and Chinou I. (2004), Chemical analysis and antimicrobial activity of Greek propolis, Planta Medica, 70, 515-519.
Melliou E. and Chinou I. (2011), Chemical constituents of selected unifloral Greek bee-honeys with antimicrobial activity, Food Chemistry, 129(2), 284-290.

Özkirim A., Çelemli Ö. G., Schiesser A., Charistos L. and Hatjina F. (2015), A comparison of the activities of Greek and Turkish propolis against Paenibacillus larvae, Journal of Apicultural Research, 53(5), 528-536.

Pellerano R.G., Uñates M.A., Cantarelli M.A., Camiña J.M. and Marchevsky E.J. (2012), Analysis of trace elements in multifloral Argentine honeys and their classification according to provenance, Food Chemistry, 134(1), 578-582.

Pisani A., Protano G. and Riccobono F. (2008), Minor and trace elements in different honey types produced in Siena County (Italy), Food Chemistry, 107(4), 1553-1560.

Pohl P., Sergiel I. and Prusisz B. (2011), Direct analysis of honey for the total content of $\mathrm{Zn}$ and its fractionation forms by means of flame atomic absorption spectrometry with solid phase extraction and ultrafiltration approaches, Food Chemistry, 125(4), 1504-1509.

Pohl P., Sergiel I. and Stecka H. (2009), Determination and Fractionation of Metals in Honey, Critical Reviews in Analytical Chemistry, 39(4), 276-288.

Roman A. (2010), Levels of copper, selenium, lead, and cadmium in forager bees, Polish Journal of Environmental Studies, 19(3), 663-669.

Saunier J.B., Losfeld G., Freydier R. and Grison C. (2013), Trace elements biomonitoring in a historical mining district (les Malines, France), Chemosphere, 93(9), 2016-2023.

Stanciu O.G, Marghitas L.A., Dezmirean D. and Campos M.G. (2011), A comparison between the mineral content of flower and honeybee collected pollen of selected plant origin (Helianthus annuus L. and salix sp.), Romanian Biotechnological Letters, 16(4), 6291-6296.

Tosi E.A., Ré E., Ortega M.E. and Cazzoli A.F. (2007), Food preservative based on propolis: bacteriostatic activity of propolis polyphenols and flavonoids upon Escherichia, Food Chemistry, 104(3), 1025-1029.

Tsiapara A.V., Jaakkola M., Chinou I., Graikou K., Tolonen T., Virtanen V and Moutsatsou P. (2009), Bioactivity of Greek honey extracts on breast cancer (MCF-7), prostate cancer (PC3 ) and endometrial cancer (Ishikawa) cells: Profile analysis of extracts, Food Chemistry, 116(3), 702-708.

Tuzen M., Silici S., Mendil D. and Soylak M. (2007), Trace element levels in honeys from different regions of Turkey, Food Chemistry, 103(2), 325-330.

Van der Steen J.J.M., Kraker J. and Grotenhuis T. (2011), Spatial and temporal variation of metal concentrations in adult honeybees (Apis mellifera L.), Environmental Monitoring and Assessment, 184(7), 4119-4126.

Van der Steen J.J.M., Kraker J. and Grotenhuis T. (2015), Assessment of the potential of honeybees (Apis mellifera L.) in biomonitoring of air pollution by cadmium, lead and vanadium, Journal of Environmental Protection, 6, 96-102.

Yang K., Wu D., Ye X., Liu D., Chen J. and Sun P. (2013), Characterization of Chemical Composition of Bee Pollen in China, Journal of Agricultural and Food Chemistry, 61(3), 708-718. 